\title{
CHANGES IN MORTALITY TRENDS OF ROAD TRAFFIC INJURIES IN LITHUANIA OVER 1971-2014
}

\author{
Birutė Strukčinskienė ${ }^{1}$, Robert Bauer², Vaiva Strukčinskaitė ${ }^{3}$, Sigutė Norkiene ${ }^{4,1}$, \\ ${ }^{1}$ Faculty of Health Sciences, Klaipeda University, Klaipeda, Lithuania, ${ }^{2}$ Austrian Road Safety \\ Board (KFV), Vienna, Austria, ${ }^{3}$ Faculty of Medicine, Vilnius University, Vilnius, Lithuania, \\ ${ }^{4}$ Klaipeda Seamen's Hospital, Klaipeda, Lithuania
}

Key words: road traffic, injury, mortality, trends.

\section{Summary}

The goal of this study was to analyze the changes in mortality trends of road traffic injuries for the whole population in transitional Lithuania over 1971 to 2014. Special attention was paid to the potential effect of the activities at macro and micro-level, and the socio-economic changes after the Independence in 1991. The data were derived from the Department of Statistics for the Government of the Republic of Lithuania, the Archives of Health Information Centre, and the Institute of Hygiene in Lithuania. The numbers have been based on the International Classification of Diseases (ICD) of the World Health Organization (WHO). Trends were estimated by the use of logarithmic regression. During the study, trends before the Independence in 1991 and after the Independence were compared.

The study revealed that during the 44-year study period, a total of 38,982 people died from road traffic injuries in Lithuania. Men deceased 3.2 times more than that of women. About $40 \%$ of those killed in road traffic crashes were pedestrians. The mortality rates of road traffic injuries showed no significant change over the pre-independence period (19711991) for the whole group. However, during the post-independence period (1992-2014), the mortality rates of road traffic injuries in the country significantly decreased for the whole population. Before the Independence (1971-1991), no change was presented nor in men and nor in women subgroups, whereas after the Independence (1992-2014), road traffic injury deaths fell significantly in both sexes. In addition, over the post-independence period, a significant decrease in pedestrian mortality trends for the whole population, and in men and women subgroups was observed. The study confirmed that sustainable preventive measures at macro and micro levels had possible impact on fatal road traffic injuries in the country. Socioeconomic changes, political reforms, education activities, safe environment creation, legislation, and improved healthcare seem to have contributed to the significant decrease of fatal road traffic injuries in transitional Lithuania. Continuous and permanent injury prevention and road safety promotion work is recommended for road safety management.

\section{Introduction}

Road traffic injuries are among major causes of mortality, injury, and financial loses. Globally over 1.2 million people die annually from road traffic crashes, and between 20 and 50 million suffer from non-fatal injuries [1, 2, 3]. About 26.000 people were killed in road crashes in the European Union (EU) countries in 2013; it was estimated that the number of road injury deaths in the EU fell by $45 \%$ between 2004 and 2013 [4]. Road traffic injuries and deaths have a terrible impact on individuals, communities and countries. They involve massive costs to often overburdened healthcare systems, occupy scarce hospital beds, consume resources and result in significant losses of productivity and prosperity, with deep social and economic repercussions. The numbers speak for themselves: this is a public health and development crisis that is expected to worsen unless action is taken [3]. Road traffic crashes are enormous burden for society, because of fatal or serious injuries, disability, socio-economic losses, and negative long-term psychological and emotional effect, along with incalculable pain for humans.

The main victims of road traffic deaths globally and in the EU are vulnerable road users (pedestrians, cyclists, and 
motorcyclists) [2, 3, 5]. In Mexico, pedestrians comprise $48 \%$ of all road traffic deaths [6]. In India, a vast majority of those killed and injured in road traffic crashes are pedestrians, motorcyclists, pillion riders, and bicyclists [7]. In South Asia and Sub-Saharan Africa, pedestrians occupy significant proportion of road traffic injuries [8]. In Australia, pedestrian deaths comprise approximately $25 \%$ of transportation injury [9]. In US, pedestrian injury remains the second leading cause of unintentional injury-related death among children aged 5-14 years [10]. In Turkey, most of child traffic deaths $(87 \%)$ are pedestrian fatalities [11].

Lithuania is a Baltic country, located in the East of Europe. Lithuania became independent from the former USSR in 1991. This country joined European Union in 2004 along with other that time middle-income countries, which had far higher mortality rates of road traffic injury than were found in high-income EU countries [5]. These are Central and Eastern European countries of the transitional economies, for which there have been little published in the international literature. It is less known, how long-term transitional conditions have influenced trends of injury mortality, especially concerning traffic injury.

In Lithuania, the external causes of deaths were the third most frequent cause of death for several years. Lithuania showed the highest mortality from external causes of deaths in the European Union (EU); this mortality exceeds the EU average of 3.2 times more for men and 1.7 times more for women. The average of the external causes of deaths per 100, 000 updated European standard population in 28 European Union countries was 45.99 (66.4 for men and 28.19 for women) (in 2013), whereas in Lithuania - 121.64 (214.19 for men and 47.97 for women). According to estimates from Eurostat, the statistical office of the European Union, Lithuania has the second highest mortality rate from fatal road traffic injuries (10.96) in EU 28 (after Romania with 12.08). In 2013, the EU 28 average of traffic crashes aged-adjusted death rates (V01-V99) per 100, 000 updated European standard population, was 5.88 (9.4 for men and 2.65 for women), whereas in Lithuania it was 10.96 (18.81 for men and 4.49 for women) [12].

In Lithuania (in 2015), the third most frequent cause of death was external cause of death and it accounted for 7.7 percent of all deaths; mortality of males due to external causes was 3 times higher than that of females. The main cause of deaths in children aged 1 to 17 years was again the external cause of death ( $49.6 \%$ of all deaths); in 2015, from external causes died 60 children (39 boys and 21 girls) [13].

Despite the fact that during the recent five years mortality from road traffic injuries (code V00-V99) decreased from 12.0 (in 2010) to 10.6 (in 2015) deaths per 100, 000 population, fatal road traffic injuries remain the main external unintentional cause of death in the country. Totally, in 2015 in road traffic crashes in Lithuania were killed 307 people: 221 men and 86 women; 161(109 males and 52 females) in urban and 146 (112 males and 34 females) in rural areas; 20 (16 boys and 4 girls) aged 0 to 19 years; 85 elderly (over 65 years) (49 men and 36 women) [13].

The goal of the paper was to analyze the changes in mortality trends of road traffic injuries for the whole population in Lithuania over 1971 to 2014. This paper considers the changing picture of fatal traffic injuries in the Baltic state of Lithuania over two periods (pre-independence and post-independence). Special attention was paid to the potential effect of the activities at macro and micro-level, and the socio-economic changes after the Independence in 1991.

\section{Materials and Methods}

The data were derived from the Department of Statistics for the Government of the Republic of Lithuania, the Archives of Health Information Centre, and the Institute of Hygiene in Lithuania from 1971 to 2014. The study period was split into two parts: before the Independence (in 1991) and after the Independence. The data for the whole population in Lithuania over 1971-1991 and over 1992-2014 were examined. Gender and number of people deceased in road traffic crashes, have been based on the International Classification of Diseases (ICD) of the World Health Organization (WHO). The classification system has changed few times during the long study period. Over 1971-1987, ICD-8 (code 161) was used. In 1988-1992, an abridged version of ICD-9 (code 161), and in 1993-1997, a full version of ICD-9 (code E 814) was used. From 1998 to 2010, ICD-10 was used (code V01-V99). Since April 2011, it was started to use ICD-10-AM (an Australian modification of ICD-10) (code V00-V99).

Death rates per 100,000 population were calculated using population estimates for each year. For estimating mortality rates trends, the logarithmic regression was applied. In regression, the $\mathrm{R}^{2}$ coefficient of determination was used, which ranges from 0 to 1 ; it is a statistical measure of how well the regression line approximates the real data points. An R square of 1.0 indicates that the regression line perfectly fits the data. The level $p \leq 0.05$ was considered statistically significant. During the study, trends before the Independence in 1991 and after the Independence were compared. The Bioethics Committee of Lithuania approved the study. 


\section{Results}

The study revealed that during the 44-year study period, a total of 38,982 people died from road traffic injuries in Lithuania: nearly 30 thousand (76\%) male and over 9 thousand (24\%) female (Figure 1). Over the study period in traffic crashes were killed 3.2 times more men than that of women. Approximately $40 \%(15,280)$ of those killed in road traffic crashes were pedestrians.

We compared the data of the pre-independence period with the data from the post-independence. Our data showed that mortality rates trend of road traffic injuries was with no significant change during the pre-independence period (1971-1991) for the whole population in Lithuania (R square $=0.013 ; p>0.05)$ (Figure $2 \mathrm{a})$. Over the post-independence period (1992-2014), the mortality rates of road traffic injuries in the country for the whole population presented significantly decreasing trend $(\mathrm{R}$ square $=0.713 ; \mathrm{p}<0.05)$ (Figure 2b).

The study revealed similar picture by gender. Road traffic injury mortality trends had no significant change over the pre-independence period (1971-1991), nor in men $(\mathrm{p}<0.05)$ and nor in women $(\mathrm{p}<0.05)$ subgroups (Figure 2a). However, after the Independence (1992-2014), the mortality rates trends of road traffic injury significantly decreased for male $(\mathrm{R}$ square $=0.721 ; \mathrm{p}<0.05)$ and for female $((\mathrm{R}$ square $=0.606 ; \mathrm{p}<0.05)$ subgroups (Figure $2 \mathrm{~b})$.

The study results showed that pedestrian mortality rates trend per 100, 000 population had no significant change over the pre-independence period (1971-1991) for the whole population ( $\mathrm{R}$ square $=0.192 ; \mathrm{p}>0.05)$ in Lithuania (Figure 3a). During the post-independence period (1992-2014) pedestrian mortality rates trend significantly decreased in the whole group $(\mathrm{R}$ square $=0.726 ; \mathrm{p}<0.05)$ (Figure $3 \mathrm{~b})$.

Over the pre-independence, in pedestrian mortality trends no significant change was observed for men $(R$

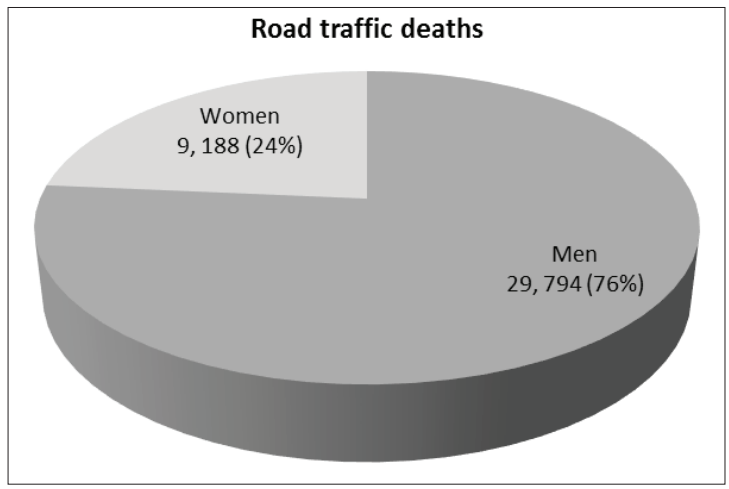

Figure 1. Road traffic deaths in Lithuania over 19712014 (by gender) square $=0.09 ; \mathrm{p}>0.05)$, whereas for women significantly increasing trend was presented $(\mathrm{R}$ square $=0.317 ; \mathrm{p}<0.05)$ (Figure 3a). However during post-independence period a significantly decreasing trend was shown for men ( $R$ square $=0.74 ; \mathrm{p}<0.05)$ and for women $(\mathrm{R}$ square $=0.69$; $\mathrm{p}<0.05$ ) (Figure 3b).

\section{Discussion}

Over four decades, Lithuania has lost nearly forty thousand people due to road traffic crashes. The data showed that mortality trends of all road traffic injuries and of pedestrians for the whole population, and for both genders significantly decreased during the post-independence period (in 1992-2014), whereas during the pre-independence period (in 1971-1991) no significant decline was observed.

During the study period, Lithuania experienced significant economic, political, and social changes. From Soviet Lithuania this country was transferred into the independent Republic of Lithuania (in 1991), and joined the European
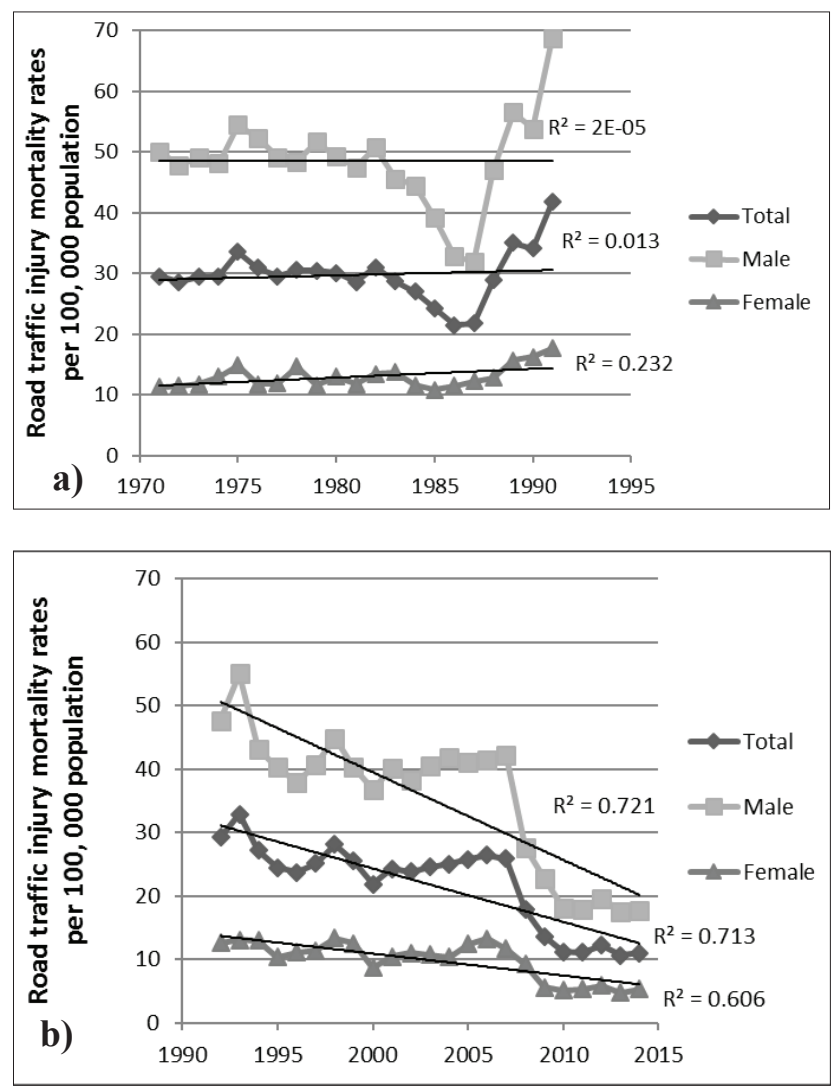

Figure 2. Mortality rates of road traffic injuries per 100, 000 population in Lithuania a) during the pre-independence period (1971-1991) and b) during the post-independence period (19922014) 
Union in 2004. Lithuania has developed from a low-income to high-income country, which has brought improvements in different areas of society.

In Soviet Lithuania, mortality from external causes was unusually high. The Soviet healthcare system was very successful in combating infectious diseases, but less effective against non-communicable diseases [14]. After the Independence in 1991, Lithuania experienced evident political and social transformations. The country faced multiple challenges associated with the transition from a socialist to a market economy system. Lithuania chose radical forms of economic and political transformations, which led to massive privatization campaigns and to the establishment of fully functioning market economies. The reforms there were more sustainable and systematic than in other former Soviet countries. Lithuania survived a serious drop in per capita income during economic difficulties in 1990, and managed to recover early $[14,15]$.

Many important changes in road safety occurred after the Independence (after 1991) in Lithuania. In 1994, the new Road Traffic Regulations came into force. In 1997, the National Road Safety Commission was established; it has control over the implementation of Road Safety policy in Lithuania. In 2000, the Road Traffic Safety Law was adopted.

The findings of this study underline the importance of continuous and sustainable safety promotion measures. One of the explanations of decline in fatal road traffic injuries could be the long-term permanent strategy of road safety promotion in the country along with the long-term development strategy of the transport system in Lithuania. The sustainable work in educating children to be have safely on the road associates with the annual national road safety competition Let's Save Young People's Lives on the Road (from 2000). At the university level, a Public Health curriculum was introduced in 1994, and at the secondary school level, a Human Safety (later called Human Safety Education) subject started from 2000. From 2006 on wards, the module Road Safety Programme for $1^{\text {st }}-8^{\text {th }}$ forms of Secondary school was integrated in this subject. These measures, amongst others, provided more information on traffic injury prevention to different spheres of society (television, internet, school, family, government), and led to more awareness of traffic injury prevention and road safety in the country.

In addition, the Health Ministry of Lithuania implemented National Injury Prevention Programmes and the Transport Ministry introduced National Road Safety Programmes that have begun in the year 2000. It provides measures related to the preparation and improvement of legislation, educational activities, road users' control, im- provement of vehicle safety, and the engineering solutions for safe roads. The changes in legislation were confirmed (for seat belt usage in the front and back seats, restraints inside the car, speed and alcohol control, and licensing systems). Road safety activities were supported by policy makers, public health officials, medical professionals, and road police at national and local levels. Pedestrian skills education, emphasis on environmentally based prevention strategies, along with improved medical treatment, highlevel intensive care equipment usage, and professional rehabilitation contributed to the significant reduction in fatal road traffic injuries.

There have been several changes related with alcohol restrictions in Lithuania, which also might have supported the decreasing mortality trends of road traffic injuries in the country over the post-independence period. In 1995 Alcohol Control Law was amended (and later improved), and the State Tobacco and Alcohol Control Agency was established. The most important measurements were:

- limitations of alcohol accessibility through taxation,
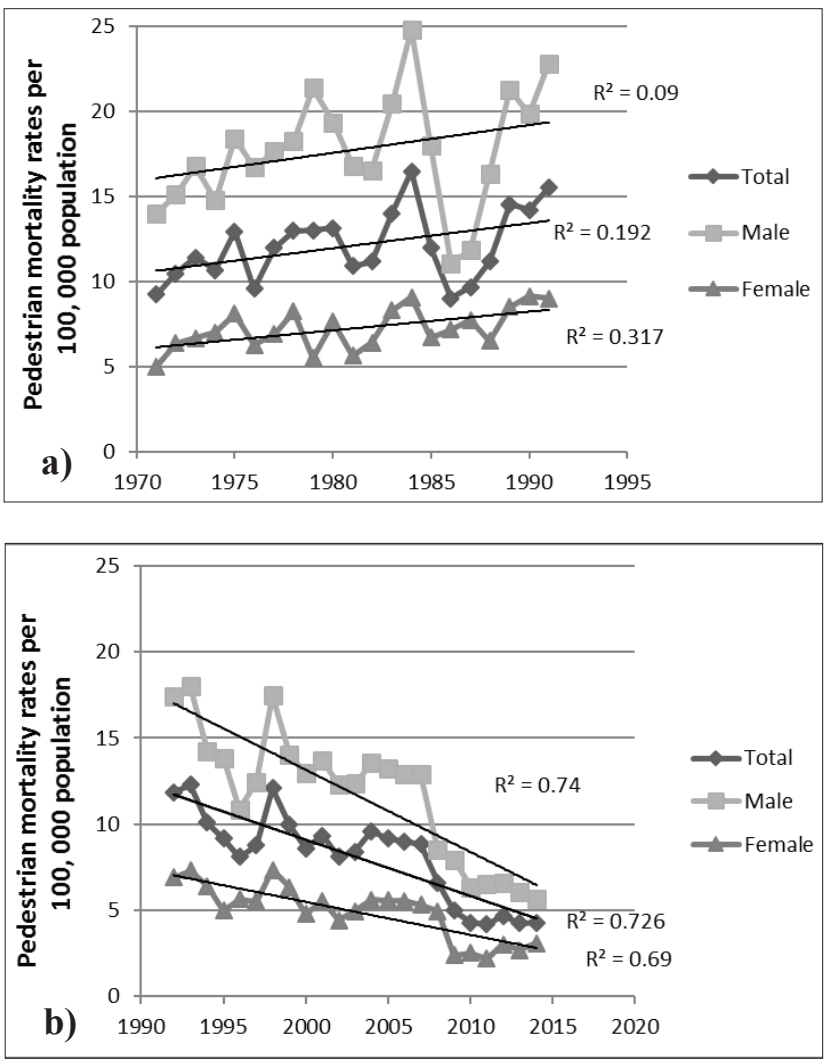

Figure 3. Pedestrian mortality rates per 100,000 population in Lithuania a) during the pre-independence period (1971-1991) and b) during the post-independence period (1992-2014) 


\section{8}

- limitations of selling hours for alcohol beverages,

- prohibition to sell and to possess alcoholic beverages to individuals aged under 18 years,

- limitations for alcohol advertisement (daytime advertising was banned on radio and TV),

- prohibition to drink, store and transport alcoholic beverages in the open containers in the body of a vehicle (from 2009),

- the permissible alcohol concentration in blood was reduced from 0.4 to 0.2 parts per million for novice drivers.

Globally, those countries, in which more attention was showed to traffic injury problem and more road safety measures have been implemented, have the lowest fatal and non-fatal road traffic injury rates. Worldwide, there are many examples of such countries: Sweden, Austria, the Netherlands, the United Kingdom, Australia, and the United States $[1,16,17,18,19,20]$. Looking at the longerterm trend, the number of road fatalities in the International Traffic Safety Data and Analysis Group (IRTAD) countries decreased by $42 \%$ between 2000 and 2014; many countries showed reductions of over $50 \%$, and some up to $70 \%$ [20]. Therefore, the change is possible. World Health Organization's recommendations for countries include addressing road safety in the long-term focus on "holistic action," a comprehensive approach involving multiple sectors that considers vehicles, road users and the road environment. In the short term, some results can be achieved with cost effective interventions such as passing laws on relevant risk factors, enforcing them, and supporting these with public awareness campaigns [3]. The implementation of more systematic road safety strategies, improvements in road infrastructure and vehicles as well as better road trauma management - all contribute [20].

Permanent, sustainable, and comprehensive safety promotion work should continue. So that common efforts on national and local levels, cross-sectoral collaboration, sustainable long-term programmes, and primary, secondary and tertiary traffic injury prevention can yield effective results in road safety promotion.

Strengths and limitations. The strength of this investigation is the long study period (over forty years) for which the analysis was performed. The analysis of longterm mortality trends is sometimes complicated because of changes in classification systems. In this study, the cause of death was classified according to the few revisions of the International Classification of Diseases (ICD) from 1971 to 2014. Statistical information in Lithuania on external causes of death has been used by WHO as quality information for their global database from 1970. Since 1970 in the Baltic States, there has been no change in the data registra- tion procedure. Statistical information from these countries is considered reliable and internationally comparable [14, $21]$. However, study data presented from over 40 years, and the possibility of uncertainties still exists.

\section{Conclusions}

Over 1971-2014, nearly forty thousand people were killed in road traffic crashes in Lithuania. Men deceased 3.2 times more than that of women. About $40 \%$ of killed were pedestrians. The mortality rate trend of road traffic injuries presented no significant change over the pre-independence period (1971-1991), however, during the post-independence period (1992-2014), it significantly decreased for the whole population in the country. The study showed similar picture by gender. During the pre-independence period (1971-1991), no significant change was observed nor in men and nor in women subgroups, however over the postindependence (1992-2014), significant decline was showed in both sexes. In addition, over the post-independence period, a significant decrease in pedestrian mortality trends for the whole population, and in men and women subgroups was observed. Sustainable preventive measures at macro and micro levels had possible impact on road traffic deaths in the country. Socioeconomic changes, political reforms, education activities, safe environment creation, legislation, and improved healthcare seem to have contributed to the significant decline in fatal road traffic injuries in transitional Lithuania. Continuous and permanent injury prevention and road safety promotion work is recommended for road safety management.

\section{Conflict of interests}

The authors declare that they have no actual or potential conflict of interest and financial conflicts in relation to this article.

\section{References}

1. Global status report on road safety. Supporting a decade of action. Geneva: World Health Organization, 2013.

2. WHO, Global Health Observatory. Road Safety.

3. Road safety: Basic facts. Geneva: World Health Organization, 2015.

4. Traffic safety basic facts on main figures. European Commission, Directorate General for Transport, 2015.

5. Bauer R, Steiner M. Injuries in the European Union: Statistics summary 2005-2007. Viena: KfV, EuroSafe, 2009.

6. Bartels D, Bhalla K, Shahraz S, Abraham J, Lozano R, Murray $\mathrm{CJ}$. Incidence of road injuries in Mexico: country report. International Journal of Injury Control and Safety Promotion 2010; 17 (3): 169-176.

http://dx.doi.org/10.1080/17457300903564553 
7. Gururaj G. Road traffic deaths, injuries and disabilities in India: current scenario. National Medical Journal of India 2008; 21 (1): 14-20.

8. Hyder AA, Muzaffar SS, Bachani AM. Road traffic injuries in urban Africa and Asia: a policy gap in child and adolescent health. Public Health 2008; 122(10): 1104-1110.

http://dx.doi.org/10.1016/j.puhe.2007.12.014

9. Kimble R, Wallis B, Nixon J, Watt K, Cass D, Gillen T, Griffin B. 10 year review of low speed vehicle run-overs in $0-15$ years olds across Queensland. Injury Prevention 2010; 16: A97. DOI: 10.1136/ip. 2010. 029215.350.

10. Chakravarthy B, Vaca FE, Lotfipour S, Bradley D. Pediatric pedestrian injuries: emergency care considerations. Pediatric Emergency Care 2007; 23 (10): 738-744.

http://dx.doi.org/10.1097/PEC.0b013e318156acea

11. Goren S, Subasi M, Gurkan F, Tirasci Y, Acar K. Child pedestrian fatalities in Diyarbakir, Turkey. Saudi Medical Journal 2005; 26 (7): 1116-1118.

12. Eurostat's database. http://ec.europa.eu/eurostat (retrieved 16 May 2016).

13. Causes of death 2015. Vilnius: Health Information Centre of Institute of Hygiene, 2016.

14. Grigoriev P, Shkolnikov V, Andreev E, Jasilionis D, Jdanov D, Mesle F, Vallin J. Mortality in Belarus, Lithuania, and Russia: Divergence in recent trends and possible explanations. European Journal of Population 2010; 26: 245-274.

http://dx.doi.org/10.1007/s10680-010-9210-1

15. Popov V. Shock therapy versus gradualism reconsidered: Lessons from transition economies after 15 years of reforms. Comparative Economic Studies 2007; 49: 1-31. http://dx.doi.org/10.1057/palgrave.ces.8100182

16. Sonkin B, Edwards P, Roberts I, Green J. Walking, cycling and transport safety: An analysis of child road deaths. Journal of the Royal Society of Medicine 2006; 99: 204-405.

http://dx.doi.org/10.1258/jrsm.99.8.402

17. Fact sheet. Road traffic injuries in the WHO European Region: The population groups and countries most affected. Copenhagen: WHO Regional Office for Europe, 2004.

18. Doukas G, Olivier J, Poulos R, Grzebieta R. Exploring differential trends in severe and fatal child pedestrian injury in New South Wales, Australia (1997-2006). Accident Analysis and Prevention 2010; 42(6): 1705-1711. http://dx.doi.org/10.1016/j.aap.2010.04.010

19. Hotz G, Kennedy A, Lutfi K, Cohn SM. Preventing pediatric pedestrian injuries. The Journal of Trauma 2009; 66(5): 14921499.

http://dx.doi.org/10.1097/TA.0b013e31819d9c9b

20. Road safety annual report 2016. Paris: OECD/ITF, OECD Publishing, 2016. http://dx.doi.org/10.1787/irtad-2016-en. http://dx.doi.org/10.1787/irtad-2016-en

21. Mathers CD, Fat DM, Inoue M, Rao Ch, Lopez AD. Counting the dead and what they died from: an assessment of the global status of cause of death data. Bulletin of the World Health Organization 2005; 83: 171-177.

\section{MIRTINGUMO NUO EISMO TRAUMŲ POKYČIAI LIETUVOJE 1971-2014 METAIS}

\section{B. Strukčinskienė, R. Bauer, V. Strukčinskaitė, S. Norkienė}

Raktažodžiai: eismo traumos, sužalojimai, mirtingumas, tendencijos.

Santrauka

Tyrimo tikslas buvo analizuoti mirtingumo nuo eismo traumų tendencijas 1971-2014 metų laikotarpiu Lietuvoje. Ypatingas dėmesys buvo skiriamas ị galimam prevencinių veiklų makro ir mikro lygiais poveikiui ir socialiniams - ekonominiams pokyčiams po Nepriklausomybės atkūrimo Lietuvoje 1991 metais. Duomenys tyrimui buvo gauti iš Statistikos departamento prie Lietuvos Respublikos Vyriausybès, Sveikatos informacijos centro archyvo ir Higienos instituto. Duomenys suvesti remiantis Pasaulio sveikatos organizacijos (PSO) Tarptautine ligų klasifikacija (TLK). Statistinei duomenų analizei taikyta logaritmine regresija. Tyrimo metu buvo palyginti dviejų laikotarpių mirtingumo nuo eismo traumų duomenys (prieš ir po 1991 metų).

Tyrimas atskleidè, kad tiriamuoju laikotarpiu per 44 metus Lietuvoje iš viso nuo eismo traumų mirẻ 38982 gyventojai. Vyrų eismo ịvykiuose žuvo 3,2 karto daugiau nei moterų. Apie $40 \%$ žuvusiujų kelių eismo avarijose buvo péstieji. Mirtingumas nuo eismo traumų laikotarpiu prieš Nepriklausomybę (1971-1991) buvo be reikšmingų pokyčių visoje Lietuvos gyventojų grupejje, o po Nepriklausomybės atkūrimo (1992-2014) mirtingumas nuo sužalojimų eisme reikšmingai sumažèjo. Prieš Nepriklausomybę (1971-1991) nei vyrų, nei moterų pogrupiuose eismo traumų mirtingumas reikšmingai nepakito, o po Nepriklausomybès atkūrimo (1992-2014) mirtingumas nuo eismo traumų reikšmingai sumažejo tiek vyrų, tiek moterų pogrupiuose. Be to, laikotarpiu po Nepriklausomybės atkūrimo buvo stebimas reikšmingas pėsčiujų mirtingumo sumažèjimas visoje gyventojų grupeje ir vyrų bei moterų pogrupiuose. Tyrimas patvirtino, kad nuosekliai vykdomos prevencinès priemonès makro ir mikro lygiais turejjo galimą poveikị mirtinų eismo sužalojimų sumažejimui šalyje. Socialiniai ir ekonominiai pokyčiai, politinės reformos, švietimo veikla, saugios aplinkos kūrimas, teisės aktai ir pagerejusi sveikatos priežiūra taip pat tikriausiai prisidejo prie statistiškai reikšmingo mirtinų eismo traumų sumažėjimo Lietuvoje. Eismo saugos valdymui yra rekomenduojama tęstinè ir nuolatinè sužalojimų prevencijos ir eismo saugos stiprinimo veikla.

Adresas susirašinèti: birutedoctor@hotmail.com

Gauta 2016-09-18 